\title{
Testing the role of chalcophile element fertility on VMS mineralization: PGE geochemistry of the volcanic rocks associated with the Jaguar and Bentley Cu-Zn VMS deposits, Western Australia
}

\author{
Jung-Woo Park ${ }^{1,2}$, Ian H. Campbell ${ }^{2}$
}

${ }^{1}$ School of Earth and Environmental Sciences, Seoul National University, Seoul 08826, Republic of Korea

${ }^{2}$ Research School of Earth Sciences, Australian National

University, Canberra 0200, Australia

We investigated the platinum-group element (PGE) geochemistry of volcanic rocks from the Teutonic Bore complex, which hosts the Jaguar and Bentley $\mathrm{Cu}-\mathrm{Zn}$ VMS deposits, in order to understand the sulfide saturation history and to constrain the role of chalcophile element fertility on the formation of volcanogenic massive sulfide (VMS) deposits.

The Jaguar and Bentley volcanic rocks are composed of basalt, andesite, dacite, and rhyolite. They show similar primitive mantle-normalized trace element patterns and continuous variations in trace elements and PGE with increasing fractionation indices such as $\mathrm{Yb}$, suggesting a comagmatic origin. The PGE behave incompatibly in the early stage of magma differentiation at $<4 \mathrm{ppm} \mathrm{Yb}$, whereas they abruptly decrease at $>4 \mathrm{ppm} \mathrm{Yb}$, indicating sulfide saturation at this point. When $\mathrm{Pd} / \mathrm{MgO}$ and $\mathrm{Pd} / \mathrm{Pt}$ are used as chalcophile element fertility indicators, the andesite before sulfide saturation $(<4 \mathrm{ppm} \mathrm{Yb})$ has the values as high as the magmas associated with porphyry $\mathrm{Cu}$-only deposits, but are 5-10 times lower than those of andesite and dacite from the modern Au-rich seafloor massive sulfide deposits. This is consistent with the Au-poor nature of the Jaguar and Bentley $\mathrm{Cu}-\mathrm{Zn}$ VMS deposits. These results imply that sulfideundersaturated andesite may have been a major source for $\mathrm{Cu}$ in the Jaguar and Bentley and that ore formation occurred shortly after sulfide saturation so that Au was largely stripped from the silicate melt whereas $\mathrm{Cu}$ was little affected. Our study shows that chalcophile element fertility may play an important role in the formation of VMS deposits, especially in controlling the $\mathrm{Au}$ contents of the ore, if the magmatic hydrothermal component is the dominant source for metals in VMS systems. 